\title{
Nóbelsverðlaun í læknisfræði fyrir uppgötvun nýrra sýklalyfja
}

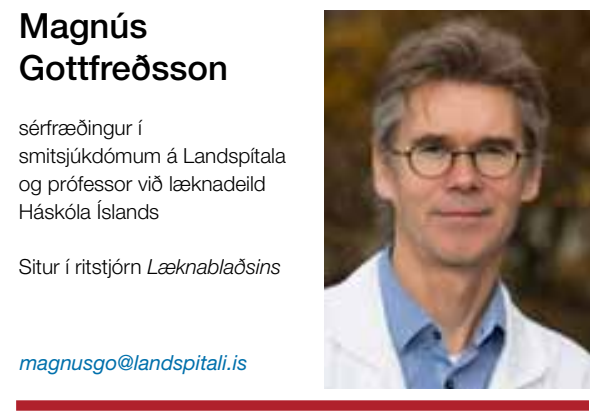

Sænska Nóbelsnefndin tilkynnti í byrjun október um verðlaunahafa ársins 2015 í lífeðlis- eða læknisfræði. Kínverska vísindakonan Youyou Tu hlaut helming verðlaunanna og hinum helmingnum skiptu á milli sín Japaninn Satoshi Omura og Bandaríkjamaðurinn William C. Campbell. Öll hafa pau verið brautryðjendur í rannsóknum á sníkjudýrasýkingum og uppgötvað ný lyf sem valdið hafa straumhvörfum í meðferð peirra. Sérstök ástæða er til að fagna pessari ákvörðun nefndarinnar, par sem rannsóknir á sníkjudýrasýkingum hafa löngum verið vanræktar prátt fyrir pær gríðarmiklu afleiðingar sem pær hafa, bæði dauðsföll og langvinnt heilsutjón um allan heim, oftast meðal peirra sem minnst mega sín.

Nóbelsverðlaunin hafa áður verið veitt fyrir uppgötvun og próun sýklalyfja en pá gegn bakteríusýkingum; Gerhard Domagk fékk verðlaunin árið 1939 fyrir uppgötvun súlfonamíða, Alexander Fleming, Ernst Chain og Howard Florey árið 1945 fyrir penicillín og Selman Waksman 1952 fyrir að einangra berklalyfið streptomycín úr jarðvegsbakteríu af ættkvíslinni Streptomyces. Рað er pví áhugavert að saga verðlaunanna nú í ár hófst með rannsóknum Satoshi Omura á jarðvegsbakteríum af sömu ættkvísl, er hann dvaldi sem gistivísindamaður í Bandaríkjunum árið 1971. Omura próaði aðferðir til að einangra Streptomyces-stofna og rækta á rannsóknastofu í miklu magni. Pegar hann hafði rannsakað mörg púsund slík afbrigði valdi hann 50 sem lofuðu góðu, meðal annars eitt sem hann fann í jarðvegi nálægt golfvelli í Ito í Japan. Campbell tók að sér að rannsaka virkni pessara bakteríuafbrigða með tilraunum í sýktum músum par sem floti úr bakteríurækt var blandað saman við hefðbundið fóður sem mýsnar átu og síðan fylgst með hvort sníkjudýrum í músunum fækkaði. Jákvæð niðurstaða mun hafa fengist úr einni mús en pað ágæta nagdýr var pó nær dauða en lífi eftir tilraunina og má pakka forsjóninni fyrir að músin lifði af! Hið virka efni var einangrað og nefnt Avermectin B1. Omura lýsti nánar bakteríunni sem framleiddi efnið. Var hún nefnd Streptomyces avermitilis, síðar Streptomyces avermectinius. Frekari rannsóknir og umbreytingar á virka efninu gáfu síðan af sér enn virkari afleiðu sem nefnd var Ivermectín. Efnið reyndist afar öflugt gegn fjölmörgum práðormategundum í görn (intestinal nematodes) og jafnframt gegn sumum práðormum utan meltingarfæra, svo sem í blóði (microfilaria). Jafnframt vakti athygli að Ivermectín var virkt gegn benzimidazoleónæmum práðormum og virtist nánast laust við aukaverkanir. Campbell varð innblásinn af pessum niðurstöðum og árið 1977 stakk hann upp á pví að Ivermectín yrði prófað á sjúklingum með Oncocerca volvulus, en sá práðormur veldur árblindu (oncocerciasis, river blindness). Niðurstöður voru sláandi - aðeins einn skammtur virtist drepa alla práðorma í blóði.

Frekari rannsóknir sýndu gríðarmikla virkni gegn fleiri tegundum práðorma, ekki síst Wucheria bancrofti og Brugia malayi sem valda langvinnri sogæðastíflu, bjúgmyndun og fílaveiki (elephantiasis) í verstu tilvikum. Um árabil hefur Merck-lyfjafyrirtækið gefið lyfið til fátækari landa par sem árblinda og práðormasýki af völdum $W$. bancrofti er landlæg. Lyfið parf aðeins að taka einu sinni eða tvisvar á ári. Árið 2012 höfðu meira en 200 milljónir manna fengið Ivermectín, ýmist eitt sér eða ásamt öðrum lyfjum. Eitt höfuðmarkmið Alpjóðaheilbrigðisstofnunarinnar WHO er að útrýma báðum sjúkdómunum innan 5-10 ára og eru markmiðin nú innan seilingar.

Malaría hefur fylgt mannkyni um árpúsunda skeið. Fyrstu heimildir um sjúkdóminn er að finna í ævafornum ritum frá Kína, Egyptalandi og Grikklandi. Nú leggst malaría á um 200 milljónir manna árlega og talið er að um hálf milljón manna látist af hennar völdum. Börn eru par í meirihluta.

Nóbelsverðlaun hafa verið veitt í prígang fyrir tímamótauppgötvanir um sjúkdóminn, sá fyrsti sem pau fékk var Ronald Ross árið 1902, breskur læknir á Indlandi sem uppgötvaði að sjúkdómurinn berst með moskítóflugum. Sá næsti var franski læknirinn Charles Leveran 1907 sem starfaði í Alsír, en hann greindi malaríusníkilinn í rauðum blóðkornum og sýndi jafnframt fram á virkni kíníns gegn sjúkdómnum. Svissneski efnafræðingurinn Paul Herman Müller fékk verðlaunin árið 1948 fyrir uppgötvun sína á skordýraeitrinu DDT sem ásamt klórókíni gaf mönnum tímabundna sigra í baráttunni við sjúkdóminn.

Mikil bakslög fylgdu í kjölfarið, meðal annars DDT-ónæmar moskítóflugur og klórókín-ónæmir malaríusníklar. Hvort tveggja leiddi til aukinnar dánartíðni vegna malaríu á 7. áratug síðustu aldar. Pær kringumstæður urðu til pess að kínverska vísindakonan Youyou Tu hóf leitina að nýjum lyfjum við malaríu. Litlu munaði að nafn hennar félli í gleymsku par sem að hún vann alla sína vinnu í Kína og var nánast ópekkt utan heimalandsins. Pað vakti athygli hennar að plantan Artemisia annua kom fyrir í mörg hundruð fornum kínverskum lækningabókum og uppskriftum að lyfjum gegn hitasótt. Pví beindust rannsóknirnar að pví að einangra efni úr plöntunni og eftir mikla byrjunarörðugleika tókst að finna efni sem virtist geta drepið alla malaríusníkla í blóði tilraunadýra. Pessar vísbendingar urðu Tu síðan hvatning til að rannsaka virknina í mönnum par sem hinar jákvæðu niðurstöður voru staðfestar. Nýr flokkur afar öflugra malaríulyfja, Artemisinín, var kominn fram á sjónarsviðið.

Samsett lyfjameðferð með Artemisinínsamböndum ásamt bættum forvörnum gegn moskítóflugum hefur valdið straumhvörfum og dregið úr dánartíðni í heiminum vegna malaríu um $47 \%$ frá síðustu aldamótum og er árangurinn jafnvel enn betri í Afríku. Heimsbyggðin á Nóbelsverðlaunahöfum ársins 2015 mikið að pakka.

\footnotetext{
Nobel prize in physiology or medicine awarded to scientists for discoveries of new antimicrobial agents Magnús Gottfredsson, MD, PhD, FACP, Consultant, Landspitali University Hospital, and Professor of medicine, Faculty of Medicine, School of Health Sciences, University of Iceland
} 